\title{
IDENTIFYING HIGHER EDUCATION FIRST-YEAR STUDENTS' REPORTED STUDYING EXPERIENCES STUDYING DURING THE PANDEMIC
}

\author{
Sanna Ruhalahti ${ }^{i}$ \\ Teija Lehto, \\ Susanna Saarinen, \\ Leena Katto \\ TAMK University of Applied Sciences, \\ Teaching and Learning Centre, \\ Finland
}

\begin{abstract}
:
The pandemic situation has been a challenge for many students. The students starting their higher education at the beginning of 2021 were facing a new kind of educational challenge due to the Covid-19 pandemic. The purpose of this study was to gain insights into first-month studies during the exceptional times. The focus was on Finnish higher education first-year students' ( $n=154)$ reported studying experiences during the COVID19 pandemic. The participants were bachelor's degree students who started their higher education studies in January 2021 in the middle of the exceptional pandemic situation caused by COVID-19. Studies during their first months have mainly been organised online, and there have been specific restrictions related to study arrangements. The study used an inductive content analysis to find out the positive and negative impacts of studying during exceptional times. The data for this study was drawn from an online questionnaire. The results indicated that students' own resources and capacity played an important role in terms of positive or negative study experiences: good study motivation, good distance-learning skills, and self-directedness helped to cope with the exceptional situation, while insufficient distance-learning skills or challenges in self-direction caused difficulties and dissatisfaction among other students. Teachers' digital pedagogical skills play a significant role, as the results of this study indicated. In addition, to teaching and learning activities, higher education institutions need to reflect on how student services, counselling, and peer support can be provided remotely. The findings of this study suggest that it is important to pay attention to students' well-being and self-directed learning skills in digital learning communities and environments. In addition, the study suggests strengthening teachers' competencies related to digital pedagogical competencies together with workload allocation and study scheduling. Also, there is a
\end{abstract}

${ }^{i}$ Correspondence: email sanna.ruhalahti@tuni.fi 
need to deepen learning community building and self-directed learning skills as a part of pedagogical support.

Keywords: higher education, first-year students, study experiences, COVID-19 pandemic

\section{Introduction}

Globally, the world's higher education students are perhaps under more outstanding stress than ever before. Even though digital technology is putting an unlimited world of information instantly at their disposal, today's undergraduates in particular have faced that their path to success is less certain than for the preceding generations (Chegg.org, 2021). According to UNESCO's (2021) report, the COVID-19 pandemic has caused abrupt and profound changes around the world. This is one of the worst shocks to education systems in decades, with the longest school closures combined with a looming recession.

To clarify, the effects of the pandemic are complex. The COVID-19 pandemic has challenged education and its developers in many levels. Bhagat and Kim (2020) pointed out that the pandemic itself has been an awakening to everyone who is involved in the higher education sector, including students, teachers, policymakers, and society alike. Furthermore, they pointed out that the pandemic has caused us to question the time, place, and process of delivering education, the role of educational institutions in promoting lifelong learning, and the line we draw between conventional and online students. In the present situation, we should not ignore the students' exceptional position. It might be a wrong assumption that all students have easy access to proper IT systems, and they have broadband connections. The pandemic situation is also quite a challenge for many students. The students starting their higher education at the beginning of 2021 were facing a new kind of educational challenge due to the Covid-19 pandemic. According to $\mathrm{Wu}$ et al. (2020), the disruption, anxiety, and uncertainty associated with the COVID-19 pandemic, particularly in the absence of a vaccine or cure at present, resonates with the notion of "uncertainty stress".

One year after the start of the pandemic, the students starting their higher education in 2021 inevitably faced an intense social and emotional stress test, as their opportunities to socialise with their fellow students were limited in the pandemic situation. In the context of Finland, higher educational institutions have been quite confident about their level of online and blended education, but Covid-19 forced them to adapt new forms of hybrid learning besides traditional online and blended learning. In many cases, a rapid leap to online learning was inevitable. Chegg.org's (2021) newly published report asks that the education sector has not been listening to what students and graduates need from higher education. This must change. But how? Therefore, the present research seeks to identify the resources that support the higher education of students in this unprecedented situation.

We present a study based on higher education first-year students' $(n=154)$ reported studying experiences during the pandemic at Tampere University of Applied Sciences 
(TAMK UAS). The purpose is to gain insights into first-month studies during the exceptional times. This paper presents a study that investigates, through qualitative inductive content analysis, the positive and negative impacts of studying during exceptional times. The following section introduces the latest research related to higher education students' experiences during the COVID-19 pandemic. Thereafter, the context of the research is presented, together with the research questions and methods. Finally, the results are discussed, and suggestions for learning design and future research are presented.

\section{Higher education students' experiences during the COVID-19 pandemic}

This article summarises some pivotal information on previous research related to higher education students' experiences related to COVID-pandemic. The focus is on first-year students' experiences.

During the pandemic, HE students globally have shown great strength, focus, and determination to keep learning. Despite all the barriers they face in their education, students are resiliently embracing their chances and looking to the future with hope. (Chegg.org, 2021) Do et al. (2021) studied Vietnamese higher education students. The results showed that about 74 percent of students are satisfied and keen on continuing online learning. But there are needs to improve online teaching competencies from the teacher's side. Comparably, Kedraka and Kaltsidisi's (2020) study concluded that the pandemic period might be seen as an opportunity for universities to improve the use of digital tools for enhanced learning and teaching experience. But there is a need to improve digital infrastructure.

Recent research has pointed out that limited social collaboration resulting from the COVID-19 pandemic may stimulate negative emotions, and social isolation may trigger stress-related emotions and lower well-being (cf. Beaunoyer et al., 2020; Miller, 2020). Marinoni, Land and Jensen (2020) summarised the situation in the European Higher education. They found that autonomous learners may have coped well with working remotely, while students with learning difficulties may have been overwhelmed. They pointed out that the pandemic crisis has aggravated the digital gap, in that not all students had access to technology and highspeed internet. The number of socially disadvantaged students has increased, and many of them have missed universities as a physical place. Distance learning does not replace social interaction with fellow students and teachers (Kedraka \& Kaltsidisi, 2020). Social relations and interactions are seen as important for the experience of learning satisfaction in online learning environments (Richardson et al., 2017). Previous research has pointed out that students' relationships with their peers are important for well-being (Weidlich \& Bastiaens, 2018; Zhao et al., 2005).

In Germany, Händel et al. (2020) investigated summer studies during the COVID19 pandemic regarding students' ( $\mathrm{n}=1826)$ digital readiness, as well as their emotional and social perceptions regarding the upcoming term. Results indicate that higher 
education students seem to be ready for digital learning. Furthermore, they state that students who were ready for digital learning reported less tension, overload, worries, social, and emotional loneliness but higher joy. Whereas students who are not ready for digital learning might not only suffer from a lack of equipment and skills to participate in digital distance courses but also from higher stress and loneliness. Similarly, Vate-ULan's (2020) previous study concluded that the relationship between online students' attitudes towards e-learning on social network sites correlated with overall satisfaction with life. Study resulted those students who had experience of e-learning had positive attitudes towards online learning, and these online students had a positive satisfaction with life.

Agasisti and Soncin (2021) studied the outbreak of Covid-19 in Italy and particularly in the Lombardy region, the first and initially most severely affected area among western countries. They concluded that it is important to ensure the continuity of students' service and constant support. In addition, reconverting all the activities (i.e. lectures, exams, laboratories, support services) online shortly and effectively was the main objective since the very beginning. Students' relationships with teachers and learning content are highly relevant to learning (cf. Weidlich \& Bastiaens, 2018; Zhao et al., 2005). Chegg.org's (2021) latest global HE surveys revealed that over half of the students reported that their mental health had suffered during COVID-19, most of whom reported heightened stress and anxiety. The mental health problems included severe ones. As many as $15 \%$ of respondents suffering from problems said that they had contemplated ending their lives, and 3\% even tried it. Nevertheless, over half of the students felt optimistic about their futures, versus only a quarter (26\%), who felt pessimistic. In every country surveyed, there were more students who felt optimistic than pessimistic.

When looking closer at first-year higher education students, $\mathrm{O}^{\prime}$ Brien and Verma (2018) found that first-year students' previous academic background, gender, and age explained lecture resource utilisation patterns. For example, they found that female and older students tended to rely more heavily on digital resources than lecture attendance. This result helps to understand the heterogeneity of student lecture engagement patterns within the first-year experience. Whereas Gradišek and Polak (2021) studied first-year higher education students in Slovenia during the pandemic. They found that the online lectures contributed the most to the students' competence development, but were not perceived as very demanding due to the passive role of the students. In addition, study reported that the online exams were similarly stressful as the exams in lecture halls and most worries related to internet connectivity. Kukkonen and Marttila (2017, 15-16) emphasise the importance of students' first-year experiences in engagement to studies. Universities can promote student engagement with pedagogic methods and learning environments that promote co-working and dialogue between students and teachers, as well as develop guidance services and study counselling. From a student's point of view, sufficient academic learning skills and realistic expectations were seen as prerequisites for studying engagement (cf. Kember \& Leung, 2005). The significance of the 
aforementioned factors has hardly diminished, despite the pandemic and the restrictions on face-to-face interaction, rather than the opposite.

When considering the Finnish context, there are several studies and surveys to look closer. According to surveys conducted by the University of Applied Sciences Students in Finland (SAMOK) in spring 2020 and 2021, the pandemic has seriously decreased the well-being of students. Both surveys had around 7000 respondents, meaning the response rate was around $6 \%$ from all Finnish UAS students. In the beginning of the pandemic, about half of the respondents felt that their well-being and motivation had decreased, while after a year up to $60 \%$ of the respondents felt the same. Already in 2020, 53\% of respondents felt that distance learning caused more stress than face-to-face learning, and the trend was even higher (60\%) with the students in the early phase of their studies. The experiences correlated with the effect that the pandemic had on the respondents' social relations in general. Those who said their social relationships were either totally or partially broken had more stress and difficulties with their wellbeing than others. After a year, the situation was even worse. The loneliness and isolation the respondents felt caused problems in their mental health and well-being, especially among the students who had moved to a new locality because of studies. Even more than health services, the respondents missed everyday face-to-face interactions and encounters with both fellow students and teachers (SAMOK, 2020, 2021).

However, some of the respondents felt that remote teaching had positive effects, such as increased flexibility and a better ability to concentrate in a quiet home environment. In both surveys, $14-18 \%$ felt that their motivation and well-being had increased during the exceptional times. The satisfaction with the quality of teaching seemed to improve during the year. While most of the respondents $(63 \%)$ in 2020 said that the transition to distance learning went quite well at their own university, half of the students still felt that the quality of teaching had deteriorated. In 2021, the students were more satisfied with the teachers' digital pedagogic skills; $55 \%$ said that the teachers had either good or excellent skills in distance teaching. Even the more critical respondents were also satisfied with most of the teachers (SAMOK, 2020, 2021).

The Finnish Education and Evaluation Centre evaluated the impacts of exceptional teaching arrangements on the realisation of equality and equity in education between March 2020 and January 2021. The conclusion was like the previously mentioned surveys: the situation is quite polarised among the higher education students. Some had found distance learning suitable for them and benefitted from flexible, asynchronous teaching and learning arrangements, while others had learning difficulties, (mental) health issues, problems with life skills, or challenging study conditions at home. The emphasis on self-regulation skills seemed to create inequality between the learners. (Karvi, 2021.) Korkeamäki and Vuorento (2021) described the same kinds of advantages and problems concerning distance learning as part of Eurostudent VII article surveys. Student interviewees suffering from mental health problems and learning difficulties felt that the (pandemic-related) higher demand for autonomy did not help them progress in 
their studies. The interviewees also reported significant differences in the arrangements for distance learning and instructing on the use of digital tools.

Holzer et al. (2021) studied Austrian and Finnish higher education students' selfreports to identify the psychological characteristics associated with students' well-being in this situation. The study concluded the relevance of perceived competence, autonomy, and self-regulated learning for university students' well-being in times of unplanned and involuntary remote studying. The competence was a strongest predictor for positive emotion. According to the study, intrinsic learning motivation was predicted by competence and autonomy in both countries. The study suggests that distance learning should be designed in a way that maximises the strengths and constrains the weaknesses of distance education.

In summary, during this research period, only a few studies were available on this specific theme. Most of the COVID-10 pandemic's higher education investigators relied heavily on the general situation.

\section{Context, Participants, and Research Questions}

The Finnish Government (2020b) declared a state of emergency in Finland over the coronavirus outbreak on 16 March 2020. Due to the pandemic, not only TAMK UAS but also practically all higher education in Finland went online or switched to hybrid mode in March 2020, continuing the collection of data.

For most learning and teaching settings, a wide variety of facilities and tools is available at TAMK UAS to implement blended learning and digital teaching. This includes digital learning environments, educational tools, and different physical classroom set-ups. Synchronous, real-time online tools, such as Zoom and Microsoft Teams appear to be the most widely used tools to create online virtual classrooms at TAMK UAS during the pandemic situation. Online-and distance-learning pedagogy has been adopted even by those teachers, who before the pandemic situation were slow or reluctant to adopt online methods in their teaching.

As far as online learning management systems are concerned, basically all the alternatives available at TAMK UAS are Moodle based.

In the spring of 2021, first-year university students ( $\mathrm{N}=195)$ in the TAMK UAS took part in an online survey concerning their first study months. The participants were bachelor's degree students who started their higher education studies in January 2021 in the middle of the exceptional pandemic situation caused by COVID-19. The participants were students from eight different degree programmes conducted in Finnish in three different fields: engineering, manufacturing, and construction $(n=84)$, health, and welfare $(n=95)$ and forestry $(n=16)$. When collecting the data, the anonymity (gender, nationality, age, etc.) of the respondents was ensured. The survey was implemented in April 2021, after 3-4 months of studies. Studies during their first months have mainly been organised online, and there have been specific restrictions related to study arrangements. 
Under the governmental recommendations, the distance education mode is still applied, with a few exceptions: the practical laboratory assignments, and studies of the first-year students remain largely on the campus. A year later, in the first months of 2021, when the first-year students' survey we are discussing in this article took place at TAMK, the first-year students, the newcomers, had some of their introductory tutoring and orientation days on campus in groups of no more than 10 students.

The aim of the online survey was to find out how the first-year students felt about the orientation days and the beginning of studies. In this study, we will focus on the students' responses to three open questions.

The research questions are regarding first-month studies during exceptional times:

1) What kinds of things had a positive impact on studies during exceptional times?

2) What kinds of things had a negative impact on studies during exceptional times?

\section{Data and analysis}

The survey gathered 195 students' responses, which represented almost half $(47.5 \%)$ of the target group. This study consisted of students $(n=154)$ who answered open-ended questions concerning the exceptional situation. The data from the open-space questions were transcribed and analysed using qualitative inductive content analysis (Schreier, 2012) and Atlas.ti 9.0.24 software. The main emphasis in inductive content analysis lies on the data. This means that the units of analysis are not predefined and that the theory is constructed based on the data. Inductive content analysis requires simplification of the data and the formation of concepts that reliably describe the matter at hand. Data quantification can be used to support content analysis, as it quantifies how many participants express a certain matter (Schreier 2012).

The research group carefully studied the data carefully. The code categories and subcategories (Annex 1) were decided on together in the research group. By codes, we mean, in this context, the semantic labels or tags we created to analyse the student feedback. To ensure that the framework of codes was balanced, not favouring either positive or negative outcomes, equal numbers of positive and negative codes were added to the classification table. Each positive code had a corresponding negative counterpart in the classification of codes.

The data were categorised and analysed according to the factors raised from the students' open responses. The unit of analysis was a word, a sentence, or a short expression. A student's expression may include many analysing codes. The main coding categories were formed in a data-driven manner. In addition, the structure of the main and subcategories was developed by reflecting on the empirical studies. The categories were revised iteratively, and researcher triangulation was used to increase the validity of research findings. Firstly, the data was coded and quantified. After the analysis, the code categorisation was updated by the research group by combining classes with similar contents. The data clustering framework was used for the quantification and analysis of 
the data. The inductive content analysis focused on identifying the significance and elements of students' experiences during exceptional times.

\section{Results}

\subsection{Positive impact on studies during exceptional times}

The aim of our first research question was to find out about the students' experiences of the positive impact on studying during the exceptional times. Table 1 describes the frequencies of the codes indicating a positive impact on studies, as expressed by the students.

Table 1: Students' experiences of positive impact factors on studies $(\mathrm{f}=373)$

\begin{tabular}{|l|c|}
\hline Code & Frequency (f) \\
\hline Flexible participation opportunities & 50 \\
\hline Good study motivation & 46 \\
\hline Functioning learning community & 33 \\
\hline Active peer support in the group & 32 \\
\hline Good distance-learning skills & 20 \\
\hline Efficient use of time & 19 \\
\hline Learning tasks well designed & 18 \\
\hline Self-directedness & 18 \\
\hline Teachers' good digital pedagogical skills & 16 \\
\hline Working daily routines & 14 \\
\hline Scheduling well designed & 12 \\
\hline Well-functioning telecommunications & 10 \\
\hline Well-functioning learning environments & 10 \\
\hline Good health & 10 \\
\hline Topic suitable for distance education & 10 \\
\hline Well-functioning devices and software & 9 \\
\hline Methods promoting interaction & 8 \\
\hline Motivating teacher & 8 \\
\hline Healthy lifestyle & 6 \\
\hline Social support network & 6 \\
\hline Good distance-learning facilities & 5 \\
\hline Content relevant and up-to-date & 3 \\
\hline Easily approachable teacher or tutor & 3 \\
\hline Study counselling well arranged & 3 \\
\hline Professional networks & 2 \\
\hline Balanced workload in studies & 1 \\
\hline Well-functioning organisation of resources and teaching & 1 \\
\hline
\end{tabular}

The results indicate that the flexible participation opportunities $(f=50)$ were valued above all by the students in the exceptional pandemic learning context. As one student reported: "Distance learning is perfect for me, in theoretical subjects contact teaching gives no added value". It was noteworthy that up to 46 students experienced good study 
motivation despite the exceptional times. One of the students expressed his/her mood like this: "So far I am well, and my study motivation and enthusiasm are high".

The high frequencies of the students' experiences of a functioning learning community $(\mathrm{f}=33)$ and active peer support $(\mathrm{f}=32)$ were a positive surprise for the research team. The students' statements of "good team spirit" or "sense of community" are indicators of a functioning learning community. A student reported how their study group had been giving peer support to each other: "We made our own WhatsApp group where grouping took place better than in guided classes. We discuss this and that with our fellow students". However, in respect to these two code units, the results were to a large extent divided, as we can conclude when comparing the corresponding negative coding units in Table 2 below.

As many as 20 students expressed having good distance-learning skills. A student's self-directedness $(\mathrm{f}=18)$ is semantically close to good distance-learning skills, and these two coding units consistently have nearly equal frequencies. One of the students reflects his/her distance-learning habits like this: "It gets better and better when I just got started". Another one shows self-directedness by recommending "doing tasks consistently and almost as soon as they are assigned".

Efficient use of time ( $\mathrm{f}=19)$ was quite highly valued by the students. One of them sums it up neatly: "Distance learning has been useful, as I can attend while ill. In the mornings I can sleep a little longer and the trips don't take my time or money". As many as 18 students felt that even in the exceptional learning situation, the learning tasks were well designed.

Teachers' good digital pedagogical skills were mentioned in 16 student responses. A student lists his/her positive experiences, indicating both the teachers' good pedagogical skills and well-designed learning tasks.

"Contact studies, versatile online courses and distance assignments, group work in the distance, flexible schedules in assignments and blended learning".

The data also revealed a few code units which, although not among the most frequent ones, might still be interesting to discuss. Working daily routines as a factor supporting studies was expressed by 14 students. Although 12 students felt that their study schedule was well designed, it is evident that the frequency could have been higher in this case. It becomes even more evident when we compare this code with its corresponding counterpart in Table 2 below. Both well-functioning telecommunications and well-functioning learning environments were mentioned no more than 10 times in the students' responses.

\subsection{Negative impact on studies during exceptional times}

The aim of the second research question was to find out about the students' experiences of the negative impact on studying during the exceptional times. Table 2 describes the 
frequencies of the codes, indicating a negative impact on studies during exceptional times.

Table 2: Students' experiences of negative impact factors on studies ( $\mathrm{f}=391)$

\begin{tabular}{|l|c|}
\hline Code & Frequency (f) \\
\hline Insufficient distance-learning skills & 49 \\
\hline Teachers' lack of digital pedagogical skills & 32 \\
\hline Insufficient peer support & 31 \\
\hline Lacking or badly functioning learning community & 31 \\
\hline Topic difficult for distance learning & 26 \\
\hline Challenges in self-direction & 26 \\
\hline Lack of information and unclear schedules & 23 \\
\hline Flaws in organisation and resourcing of teaching & 21 \\
\hline Unbalanced workload in studies & 17 \\
\hline Teacher or instructor difficult to approach & 15 \\
\hline Insufficient motivation to study & 14 \\
\hline Unclear or excessive assignments & 13 \\
\hline Little or no interaction & 11 \\
\hline Confusing or poorly functioning learning environments & 10 \\
\hline Challenges in time management & 9 \\
\hline Lacking or distracting professional networks & 9 \\
\hline Content irrelevant or out-of-date & 9 \\
\hline Impaired health or health risks & 8 \\
\hline Missing or distracting daily routines & 7 \\
\hline Malfunctioning devices and software & 6 \\
\hline Inflexible teaching arrangements & 6 \\
\hline Telecommunication problems & 5 \\
\hline Insufficient study counselling & 5 \\
\hline Lack of proper distance-learning facilities & 4 \\
\hline Unhealthy lifestyles & 2 \\
\hline Lack of social support networks & 2 \\
\hline Unmotivated or stressed teacher & 0 \\
\hline
\end{tabular}

The results showed that insufficient distance-learning skills had the greatest negative impact on learning during the exceptional period $(f=49)$. Some students had problems with time management or self-discipline and focusing on studies was perceived as challenging in the home environment. Some students also mentioned that "studying and leisure are sometimes difficult to distinguish at home". According to a few comments, distance learning involved a lot of self-studying, and the tight schedule of meetings made it necessary to review the content independently afterwards.

"During distance classes, teachers go through things really quickly, and sometimes there are situations when nearly half of the material is left for self-studying, as there is no time to go through it."

Strict schedules and the need for self-studying also emerged in connection 
with teacher's lack of digital pedagogical skills, which had the second highest frequency in codes $(\mathrm{f}=32)$. Some students felt that there was no room for critical thinking or discussion during the lessons. However, as one student wrote, nothing but "loose lessons and loose deadlines that need to be clarified" were offered. Many respondents mentioned that teachers did not consider students' entry level or prior skills. For that reason, some students became frustrated with either too slow or too fast progress on the course. Challenges in communication and guidance were also repeatedly mentioned as connected to poor pedagogical design of lessons and learning management systems.

"Then there are teachers who can do nothing but read slideshows word by word through Zoom, and help with problems is not available."

"Some Moodle platforms are so confusing that you don't want to do tasks for that reason either."

Insufficient peer support and a lacking or badly functioning learning community both had the same frequency $(\mathrm{f}=31)$ in codes and are closely connected to each other. The comments in both groups were almost the same; most of them liked not knowing their fellow students at all. For this reason, grouping, and doing group work was also felt difficult. It was quite worrying that several comments also highlighted the loneliness experienced by the students and its negative impact on learning.

"It sometimes feels like I am not a student at all, as I often feel that I am all alone. During the lectures, it becomes momentarily tangible that I am a student, but then everything goes back to "do it independently" again, and I am left alone again."

Some topics such as mathematics raised in a group topic difficult for distance learning $(f=26)$. Students thought that in contact classes, it would have been easier to ask for help from a teacher, and learning would then have been more effective. Students also missed practical work and excursions and said that there was too much theory and group work.

"Knowledge acquisition skills are very important, but not so important as to replace practical skills."

Pedagogical issues were also mentioned in connection with the difficulty of the topic: "Unclear assignments in some courses after having a live meeting at the beginning with a group and the teacher has given instructions for some larger work / project. Since then, we have been left to our own to do the task with very interpretive instructions." This feeling of being left alone was also evident in responses connected to challenges in self-direction ( $\mathrm{f}=26)$. The demand for self-direction and the amount of homework surprised most of the 
students. Many respondents admitted that they have trouble concentrating on teaching and studies at home or easily suffer from a lack of motivation. Some mentioned the need for support from teachers or fellow students.

"Pure distance learning is heavy and requires a lot of self-discipline. I would sometimes need support."

The need for support or information also raised a group lack of information and unclear schedules $(\mathrm{f}=23)$, where most of the responses claimed that there were conflicting practices in sharing schedules and other information. That led to a situation in which some students did not know even what should have been done in a course. Some students even demanded a unified way to share information: "Information too scattered, someone puts links and tasks in an email, someone in Moodle, and one just on the calendar. It shouldn't be hard to "force" everyone into one course of action."

Students also felt that there should have been more collaboration between the teachers of the different courses while planning the schedules and assignments: "Teachers do not seem to be aware of other ongoing courses, there is quite a lot of overlap and it is the responsibility of the student to point them out."

The comments in a code group flaws in organisation and resourcing of teaching $(\mathrm{f}=21)$ were quite a lot of the same as in previously presented groups. Students considered distance learning hard, the information was confusing, and teaching arrangements changed too often. The student also hoped that teaching would have been fixed in advance to be in distance mode for the whole semester or academic year, so that there would have been no need to constantly change teaching arrangements. Also, the question of teachers' resources and lack of lessons was raised in answers: "If the teacher is sick, there are no replacement lessons." And "Likewise, the teachers have not been seen, so perhaps some of the things that preoccupy the mind have not been asked in rather busy lectures. There are quite a few lectures."

From the students' point of view, the lack of lessons led to an unfair workload outside the lessons. The responses in code unbalanced workload in studies $(f=17)$ repeat that there is far too much work for credits of a course and that there is also variance in this between courses and teachers. Some students also pointed out that teachers assume that students are competent in their skills at the beginning of a course. Therefore, they felt that they needed to do extra work to reach the required level. The lack of collaboration in planning is also reflected in the accumulation of workloads: "Occasional accumulation of workload. I have noticed that it often happens that the tasks of the courses overlap, and the deadlines are the same, which creates a large point load on the workload."

There are many similar comments about asking for help from a teacher under the code teacher or instructor difficult to approach $(\mathrm{f}=15)$. 
"Although the teacher has said that she/he can be emailed at any time, I think the threshold for sending an email is high for many students."

Some students are even worried about their peers because the communication with a teacher is too slow: "I am worried about my classmates' coping because it takes a long time to get help."

In summary, from both perspectives, the results of the analysis give us important perceptions of students' experiences. There is a further need to rethink studies when the "new normal" starts, although it is time to strengthen positive impacts and deeply develop negative impacts.

\section{Discussion}

This study focused on first-year higher education students' reported experiences of studying during the pandemic. The study's aim was to gain insights into the first months' studies during the exceptional times. The results indicate that the factors supporting and weakening studying and learning experiences can be divided into different categories, ranging from teaching and learning design and technology to students' resources and capacities.

The experiences of the participants varied a lot-and are thus in line with previous studies. Like in the study of Do et al. (2021), the flexibility provided by online teaching and learning was highly valued among many students. Moreover, students' own resources and capacity played an important role in terms of positive or negative study experiences: good study motivation, good distance-learning skills, and self-directedness helped to cope with the exceptional situation, while insufficient distance-learning skills or challenges in self-direction caused difficulties and dissatisfaction among other students. Based on our study, it is not possible to identify background factors that might affect those skills. Nevertheless, it is important to recognise that the group of 'first-year students' is a very heterogeneous one with different family situations, prior working/studying experiences, study motivations, health, age, etc. This might, however, be one of the reasons for polarised distance-learning experiences among students, which has been found in several studies (cf. Karvi 2021; Korkeamäki \& Vuorento 2021; Marioni et al., 2020; SAMOK 2020, 2021). Results of this study are in line with Bhagat and Kim's (2020) study, which pointed to an emerging demand for online or distance learning and the supply of digital capabilities and competencies to make the teaching-learning experience rich and value-oriented for all learners. Based on the empirical results of our, and several other studies, it is crucial to first identify students at risk for lower academic success and then support them in developing their learning skills in all areas.

Another factor often mentioned by students in both positive and negative ways was related to interaction and community. Despite the challenging situation, some degree programmes or student groups managed to create a functioning learning community and ways to promote active peer support. At the same time, approximately the same number 
of students reported suffering from a lack of those. This is in line with the results of recent research that emphasises the importance of social interaction and collaboration as sources of students' well-being and learning satisfaction (Beaunoyer et al., 2020; Miller, 2020; Kedraka \& Kaltsidisi, 2020). Also, the surveys of SAMOK $(2020,2021)$ indicated that the respondents missed everyday face-to-face interactions and encounters with both fellow students and teachers. Moreover, the earlier studies show that the dropout rates of pure online programmes are much higher than those of traditional or blended programmes (cf. Simpson, 2013; Vogel et al., 2018).

Teachers' digital pedagogical skills play a significant role, as the results of this study indicate. In addition to teaching and learning activities, higher education institutions need to reflect on how student services, counselling, and peer support can be provided remotely (Marioni et al., 2020). However, both online and face-to-face learning are needed - while flexibility provided by distance learning is seen as an advantage, the need for a learning community and face-to-face interaction-especially in the early phases of studies - seems obvious. Like Holzer et al. (2021) suggest, distance learning should be designed in a way that maximises the strengths and constrains the weaknesses of distance education. Based on our study results, this should be a highlighted future direction in the context of higher education.

This study does have some limitations. Since the number of participants in our featured study was rather small, no wider or more general conclusions could be drawn based on the study results. The collection of further data through face-to-face or online interviews would have benefitted this study (Williams, 2005).

As the exceptional situation seems to persist in higher education institutions, it is important to pay attention to our students' well-being and self-directed learning skills in digital learning communities and environments. Finnish Government announced a special grant that is aimed at universities, student organisations, student unions and actors within the administration of the Ministry of Education and Culture, whose main goal is to promote the well-being of university students. The grant can be used, for example, to alleviate the students' experience of loneliness, develop support activities, or strengthen the digital learning community spirit. (Finnish Government, 2020a.) In future studies, it would be beneficial to deepen understanding regarding student's experiences during these exceptional times.

\section{Implications}

When lensing the needs of higher education pedagogy implications, Finland Trade Union of Education (2020) sorted out that Finnish higher education has responded to the exceptional times well, and teacher's competences related to digital teaching are better than in other school levels.

Since the beginning of 2020 Tampere University and Tampere University of Applied Sciences (TAMK) constitute the Tampere Universities community. The Tampere Universities community has arranged several online training sessions focusing 
on how to quickly transform existing contact teaching to online learning - in other words, how to flexibly leap to a pandemic mode of teaching and learning. To accelerate the higher education pedagogy implementation of the pandemic and postpandemic situations, the study it's part suggests strengthening teachers' competencies related to digital pedagogical competencies together with workload allocation and study scheduling. Also, there are a need to deepen learning community building and selfdirected learning skills as a part of pedagogical support.

\section{Acknowledgements}

This article has been written as part of TAMK UAS's development and research activities on the newly established Teaching and Learning Centre. This is part of the Tampere Universities community network that brings together higher education pedagogical expertise and the information and services needed by teachers.

\section{About the Authors}

PhD Ruhalahti, Sanna works as a Head of Teaching and Learning Centre (TAMK) and Principal lecturer at TAMK's School of Pedagogical Innovations. Her research interests cover deeper and dialogical learning, pedagogical learning design and higher education pedagogy. https://orcid.org/0000-0002-5554-1600.

MA Lehto, Teija works as a Senior Adviser at TAMK Education Development Services. She is an experienced developer of online and digital education, a member of the Finnish national higher education electronic examinations (EXAM) team and the TAMK contact person for the Finnish national higher education cross-examinations system. https://orcid.org/0000-0002-9512-0069.

M. Soc.Sc. Saarinen, Susanna works as a Senior Adviser at TAMK Education Development Services. She is a member of the national career monitoring group of Finnish UASes and her interests cover student feedback systems and higher education pedagogy.

M.Sc. Katto, Leena works as a Senior Adviser at TAMK Pedagogical Innovations and as a team leader of Ubiquitous Learning Environments team. She has been working on educational technology since 2006 and has a strong interest in learning design, learning analytics and digital learning. https://orcid.org/0000-0002-3252-4648.

\section{References}

Agasisti, T., \& Soncin, M. (2021) Higher education in troubled times: on the impact of Covid-19 in Italy, Studies in Higher Education, (46)1, 86-95, https://doi.org/10.1080/03075079.2020.1859689

Beaunoyer, E., Dupéré, S., \& Guitton, M.J. (2020). COVID-19 and digital inequalities: Reciprocal impacts and mitigation strategies. Computers in Human Behavior, 111. https://doi.org/10.1016/j.chb.2020.106424 
Bhagat, S., \& Kim, D. J. (2020). Higher education amidst COVID-19: Challenges and silver Lining. Information Systems Management, 37(4), 366-371.

Chegg.org. (2021). Global student survey. https://www.chegg.com/about/wpcontent/uploads/2021/03/Chegg.org-global-student-survey-21.pdf

Do, T.M.T., Ngo, V.T., Hoang, A.Q., Nguyen, T.L.G., Truong, D.N., Le, M.H., Vo, T.N., Ruhalahti, S., \& Kunnari, I. (2021). Evaluating online learning and teaching at the University of Technology and Education Ho Chi Minh City during [the] Coronavirus pandemic. Journal of Technical Educational Science, 62, 17-27.

Finnish Government. (2020a). Korkeakouluopiskelijoiden hyvinvointia ja ohjausta tuetaan erityisavustuksilla [The well-being and guidance of higher education students are supported with special grants]. https://valtioneuvosto.fi/L1410845/korkeakouluopiskelijoiden-hyvinvointia-ja-ohjausta-tuetaanerityisavustuksilla

Finnish Government. (2020b). Government, in cooperation with the President of the Republic, declares a state of emergency in Finland over coronavirus outbreak. 16 March 2020. https://valtioneuvosto.fi/en/-//10616/hallitus-totesi-suomen-olevanpoikkeusoloissa-koronavirustilanteen-vuoksi

Gradišek, P., \& Polak, A. (2021). Insights into learning and examination experience of higher education students during the Covid-19 pandemic. Journal of Contemporary Educational Studies, 72(138).

Holzer, J., Lüftenegger, M., Korlat, S., Pelikan, E., Salmela-Aro, K., Spiel, C., \& Schober, B. (2021). Higher education in times of COVID-19: University students' basic need satisfaction, self-regulated learning, and well-being. AERA Open. https://doi.org/10.1177/23328584211003164

Händel, M., Stephan, M., Gläser-Zikuda, M., Kopp, B., Bedenlier, S., \& Ziegler, A. (2020). Digital readiness and its effects on higher education students' socioemotional perceptions in the context of the COVID-19 pandemic. Journal of Research on Technology in Education. https://doi.org/10.1080/15391523.2020.1846147

Karvi. (2021). Poikkeuksellisten opetusjärjestelyjen vaikutukset tasa-arvon ja yhdenvertaisuuden toteutumiseen eri koulutusasteilla. Osa III: Kansallisen arvioinnin yhteenveto ja suositukset. [Impacts of the exceptional teaching arrangements on the realisation of equality and equity at different levels of education. Part III of the evaluation project: Summary and recommendations of the national evaluation]. Kansallinen koulutuksen arviointikeskus, julkaisut 8:2021. https://karvi.fi/app/uploads/2021/04/KARVI 0821.pdf

Kedraka, K., \& Kaltsidis, C. (2020). Effects of the Covid-19 pandemic on university pedagogy: Students experiences and considerations. European Journal of Education Studies, 7(8). http://dx.doi.org/10.46827/ejes.v7i8.3176.

Kember, D., \& Leung, D. Y. P. (2005). The influence of active learning experiences on the development of graduate capabilities. Studies in Higher Education, 30(2), 155-170.

Korkeamäki, J., \& Vuorento, M. (2021). Ilmoitettujen terveys- ja toimintarajoitteiden vaikutus korkeakouluopiskeluun.[Students with self-reported health problems 
and disabilities in higher education Eurostudent VII article series]. Publications of the Ministry of Education and Culture, Finland 2021:16. http://urn.fi/URN:ISBN:978952-263-841-0

Kukkonen, H., \& Marttila, L. (2017). Kuviteltua todellisuutta-ammattikorkeakoulu oppimisen ja opiskelun ympäristönä. [Imaging the future-University of Applied Science as a learning environment]. Tampere. Tampereen ammattikorkeakoulun julkaisuja.

Marinoni, G., Land, H., \& Jensen, T. (2020). The impact of COVID-19 on higher education around the world. Paris. International Association of Universities.

Miller, G. (2020). Social distancing prevents infections, but it can have unintended consequences. Science. https://doi.org/10.1126/science.abb7506

O'Brien, M., \& Verma, R. (2019). How do first-year students utilize different lecture resources? Higher Education, 77(1), 155-172. https://doi.org/10.1007/s10734-018$\underline{0250-5}$

Richardson, J. C., Maeda, Y., Lv, J., \& Caskurlu, S. (2017). Social presence in relation to students' satisfaction and learning in the online environment: A meta-analysis. Computers in Human Behavior, 71, 402-417.

SAMOK (2020). AMK-opiskelijoiden kokemuksia etäopiskelusta.[University of applied sciences students in Finland: UAS students' experiences of the distance learning]. https://samok.fi/wp-content/uploads/2020/05/amk-opiskelijoidenkokemuksia-etaopiskelusta.pdf .pdf

SAMOK (2021). AMK-opiskelijoiden etäopiskelukyselyn tulokset. [University of Applied Sciences Students in Finland: Results of the distance learning survey for UAS students]. https://samok.fi/wp-content/uploads/2021/05/amk-opiskelijoidenetaopiskelukyselyn-tulokset-2021.pdf

Schreier, M. (2012). Qualitative content analysis in practice. London, UK: Sage.

Trade Union of Education. (2020). OAJ:n kysely koskien opetuksen poikkeusjärjestelyitä keväällä 2020. [ OAJ's survey related to exceptional teaching settings in the spring 2020]. https://www.oaj.fi/ajankohtaista/uutiset-ja-tiedotteet/2020/koronaviruskysely/

UNESCO. (2021). Mission: Recovering education in 2021. https://unesdoc.unesco.org/ark:/48223/pf0000377496?posInSet=4\&queryId=b66bc c00-bd13-4a89-bdc4-8cc73d156a78

Simpson, O. 2013. "Overcoming the 'distance education deficit' through proactive motivational support". Distance Education in China, 7.

Vate-U-Lan, P. (2020). Psychological impact of e-learning on social network sites: Online students' attitudes and their satisfaction with life. Journal of Computing in Higher Education, 32(1), 27-40. https://doi.org/10.1007/s12528-019-09222-1

Vogel, C., Hochberg, J., Hackstein, S., Bockshecker, A., Bastiaens, T.J., \& Baumöl, U. (2018). Dropout in distance education and how to prevent it. In T. Bastiaens, J. Van Braak, M. Brown, L. Cantoni, M. Castro, R. Christensen, G. Davidson-Shivers, K. DePryck, M. Ebner, M. Fominykh, C. Fulford, S. Hatzipanagos, G. Knezek, K. Kreijns, G. Marks, E. Sointu, E. Korsgaard Sorensen, J. Viteli, J. Voogt, P. Weber, 
E. Weippl, \& O. Zawacki-Richter (Eds.), Proceedings of EdMedia: World Conference on Educational Media and Technology (pp. 1788-1799). Amsterdam, Netherlands: Association for the Advancement of Computing in Education (AACE).

Williams, D. D. (2005). Measurement and assessment supporting evaluation in online settings. In D. D. Williams (Ed.), Online assessment, measurement and evaluation: Emerging practices (pp. 1-8). Hershey, PA: Information Science Publishing.

Wu, D., Yu, L., Yang, T., Cottrell, R., Peng, S., Guo, W., \& Jiang, S. (2020). The impacts of uncertainty stress on mental disorders of Chinese college students: Evidence from a nationwide study. Frontiers in Psychology, 11(243), 1-9. https://doi.org/10.3389/fpsyg.2020.00243

Weidlich, J., \& Bastiaens, T. J. (2018). Technology Matters-The Impact of Transactional Distance on Satisfaction in Online Distance Learning. The International Review of Research in Open and Distributed Learning, 19(3). https://doi.org/10.19173/irrodl.v19i3.3417

Zhao, Y., Lei, J., Yan, B., Lai, C., \& Tan, S. (2005). What makes the difference? A practical analysis of research on the effectiveness of distance education. The Teachers' College Record, 107, 1836-1884. 


\section{Appendix}

\section{Classification of coding}

Coding presented below and used in this study to analyse the students' feedback was created by the authors of this article.

\begin{tabular}{|c|c|}
\hline Category & Code \\
\hline $\begin{array}{l}\text { 1.1. Successful teaching } \\
\text { and learning design }\end{array}$ & $\begin{array}{l}\text { 1.1.1. Motivating teacher } \\
\text { 1.1.2. Scheduling well designed } \\
\text { 1.1.3. Learning tasks well designed } \\
\text { 1.1.4. Easily approachable teacher or tutor } \\
\text { 1.1.5. Topic suitable for distance education } \\
\text { 1.1.6. Teachers' good digital pedagogical skills } \\
\text { 1.1.7. Balanced workload in studies } \\
\text { 1.1.8. Content relevant and up-to-date } \\
\text { 1.1.9. Well-functioning organisation of resources and teaching }\end{array}$ \\
\hline $\begin{array}{l}\text { 1.2. Interaction } \\
\text { and community }\end{array}$ & $\begin{array}{l}\text { 1.2.1. Functioning learning community } \\
\text { 1.2.2. Active peer support in the group } \\
\text { 1.2.3. Methods promoting interaction } \\
\text { 1.2.4. Study counselling well arranged }\end{array}$ \\
\hline $\begin{array}{l}\text { 1.3. Digitalisation } \\
\text { and technology }\end{array}$ & $\begin{array}{l}\text { 1.3.1. Well-functioning telecommunications } \\
\text { 1.3.2. Well-functioning devices and software } \\
\text { 1.3.3. Well-functioning learning environments }\end{array}$ \\
\hline $\begin{array}{l}\text { 1.4. Students' resources } \\
\text { and capacity }\end{array}$ & $\begin{array}{l}\text { 1.4.1. Self-directed } \\
\text { 1.4.2. Healthy lifestyle } \\
\text { 1.4.3. Working daily routines } \\
\text { 1.4.4. Good distance-learning skills } \\
\text { 1.4.5. Good study motivation }\end{array}$ \\
\hline 1.5. Life situation & $\begin{array}{l}\text { 1.5.1. Social support network } \\
\text { 1.5.2. Professional networks } \\
\text { 1.5.3. Good health } \\
\text { 1.5.4. Good distance-learning facilities }\end{array}$ \\
\hline 1.6. Flexibility & $\begin{array}{l}\text { 1.6.1. Efficient use of time } \\
\text { 1.6.2. Flexible participation opportunities }\end{array}$ \\
\hline
\end{tabular}


Coding for students' experiences of negative impact factors on studies.

\begin{tabular}{|c|c|}
\hline Category & Code \\
\hline $\begin{array}{l}\text { 2.1. Unsuccessful teaching } \\
\text { and learning design }\end{array}$ & $\begin{array}{l}\text { 2.1.1. Unmotivated or stressed teacher } \\
\text { 2.1.2. Lack of information, unclear schedules } \\
\text { 2.1.3. Unclear or excessive assignments } \\
\text { 2.1.4. Teacher or instructor difficult to approach } \\
\text { 2.1.5. Topic difficult for distance learning } \\
\text { 2.1.6. Teachers' lack of digital pedagogical skills } \\
\text { 2.1.7. Unbalanced workload in studies } \\
\text { 2.1.8. Content irrelevant or out-of-date } \\
\text { 2.1.9. Flaws in organisation and resourcing of teaching }\end{array}$ \\
\hline $\begin{array}{l}\text { 2.2. Interaction } \\
\text { and community challenges }\end{array}$ & $\begin{array}{l}\text { 2.2.1. Lacking or badly functioning learning community } \\
\text { 2.2.2. Insufficient peer support } \\
\text { 2.2.3. Little or no interaction } \\
\text { 2.2.4. Insufficient study counselling }\end{array}$ \\
\hline $\begin{array}{l}\text { 2.3. Digitalisation } \\
\text { and technology challenges }\end{array}$ & $\begin{array}{l}\text { 2.3.1. Telecommunication problems } \\
\text { 2.3.2. Malfunctioning devices and software } \\
\text { 2.3.3. Confusing or poorly functioning learning environments }\end{array}$ \\
\hline $\begin{array}{l}\text { 2.4. Challenges in students' } \\
\text { resources and capacities }\end{array}$ & $\begin{array}{l}\text { 2.4.1. Challenges in self-direction } \\
\text { 2.4.2. Unhealthy lifestyles } \\
\text { 2.4.3. Missing or distracting daily routines } \\
\text { 2.4.4. Insufficient distance-learning skills } \\
\text { 2.4.5. Insufficient motivation to study }\end{array}$ \\
\hline $\begin{array}{l}\text { 2.5. Challenges } \\
\text { in life situation }\end{array}$ & $\begin{array}{l}\text { 2.5.1. Lack of social support networks } \\
\text { 2.5.2. Lacking or distracting professional networks } \\
\text { 2.5.3. Impaired health or health risks } \\
\text { 2.5.4. Lack of proper distance-learning facilities }\end{array}$ \\
\hline 2.6. Inflexibility & $\begin{array}{l}\text { 2.6.1. Challenges in time management } \\
\text { 2.6.2. Inflexible teaching arrangements }\end{array}$ \\
\hline
\end{tabular}



to copy, distribute, transmit or adapt the article content, providing a proper, prominent and unambiguous attribution to the authors in a manner that makes clear that the materials are being reused under permission of a Creative Commons License. Views, opinions and conclusions expressed in this research article are views, opinions and conclusions of the author(s). Open Access Publishing Group and European Journal of Education Studies shall not be responsible or answerable for any loss, damage or liability caused in relation to/arising out of conflicts of interest, copyright violations and inappropriate or inaccurate use of any kind content related or integrated into the research work. All the published works are meeting the Open Access Publishing requirements and can be freely accessed, shared, modified, distributed and used in educational, commercial and non-commercial purposes under a Creative Commons Attribution 4.0 International License (CC BY 4.0). 